\title{
SISTEM DETEKSI PENYAKIT PENGEROPOSAN TULANG DENGAN METODE JARINGAN SYARAF TIRUAN BACKPROPAGATION DAN REPRESENTASI CIRI DALAM RUANG EIGEN
}

\author{
Is Mardianto ${ }^{1}$; Dian Pratiwi ${ }^{2}$ \\ ${ }^{1,2}$ Jurusan Teknik Informatika, Fakultas Teknologi Industri, Universitas Trisakti, \\ Jln. Kyai Tapa No.1, Grogol, Jakarta Barat 11440 \\ georadar@yahoo.com
}

\begin{abstract}
There are various ways to detect osteoporosis disease (bone loss). One of them is by observing the osteoporosis image through rontgen picture or X-ray. Then, it is analyzed manually by Rheumatology experts. Article present the creation of a system which could detect osteoporosis disease on human, by implementing the Rheumatology principles. The main areas identified were between wrist and hand fingers. The working system in this software included 3 important processing, which were process of basic image processing, pixel reduction process, pixel reduction, and artificial neural networks. Initially, the color of digital X-ray image (30 x 30 pixels) was converted from RGB to grayscale. Then, it was threshold and its gray level value was taken. These values then were normalized to an interval [0.1, 0.9], then reduced using a PCA (Principal Component Analysis) method. The results were used as input on the process of Backpropagation artificial neural networks to detect the disease analysis of X-ray being inputted. It can be concluded that from the testing result, with a learning rate of 0.7 and momentum of 0.4, this system had a success rate of 73 to 100 percent for the non-learning data testing, and 100 percent for learning data.
\end{abstract}

Keywords: osteoporosis, image processing, PCA, artificial neural networks

\begin{abstract}
ABSTRAK
Ada berbagai cara untuk mendeteksi penyakit osteoporosis (pengeroposan tulang), salah satunya adalah dengan melihat gambaran osteoporosis melalui foto rontgen atau X-ray. Kemudian, dianalisis secara manual oleh pakar Rheumatologi. Artikel menunjukkan pengembangan suatu sistem yang dapat mendeteksi penyakit osteoporosis pada manusia dengan menerapkan prinsip Rheumatologi. Daerah utama yang diidentifikasi adalah antara pergelangan tangan hingga jari tangan. Sistem kerja di dalam perangkat lunak ini meliputi 3 pemrosesan penting, yaitu proses pengolahan citra dasar, proses reduksi piksel, dan proses jaringan syaraf tiruan. Awalnya, citra X-ray digital (30 x 30 piksel) dilakukan pengkonversian warna dari RGB ke grayscale. Kemudian, di-thresholding dan diambil nilai gray level-nya. Nilai-nilai tersebut selanjutnya dinormalisasi ke interval [0.1, 0.9], lalu direduksi menggunakan metode PCA (Principal Component Analysis). Hasilnya dijadikan input pada proses jaringan syaraf tiruan Backpropagation untuk mengetahui analisis penyakit dari X-ray yang dimasukkan. Disimpulkan dari hasil pengujian dengan learning rate sebesar 0.7 dan momentum sebesar 0.4, sistem ini memiliki tingkat keberhasilan 73 hingga 100 persen untuk uji data non-learning, dan 100 persen untuk data learning.
\end{abstract}

Kata kunci: osteoporosis, pengolahan citra, PCA, jaringan syaraf tiruan

\section{PENDAHULUAN}

\section{Latar Belakang}

Dewasa ini, kebutuhan akan piranti pengenal/ pendeteksi penyakit yang handal sangat dibutuhkan. Pengembangan teknologi pengenalan berupa sistem kecerdasan buatan menjadi sangat penting dan membantu karena selain mempermudah, juga mempercepat pekerjaan manusia. Salah satu ilmu yang mendukung teknologi tersebut adalah artificial neural network (jaringan syaraf tiruan), di mana dalam 10 tahun terakhir pengaplikasiannya telah banyak dikembangkan di berbagai bidang. Misalnya, dalam bidang kedokteran di Indonesia, yang sudah banyak menggunakan teknologi jaringan syaraf tiruan untuk memudahkan pekerjaan paramedis maupun dokter dalam mendeteksi setiap penyakit pasien. Beberapa alat berbasiskan teknologi jaringan syaraf tiruan yang telah digunakan di rumah-rumah sakit diantaranya adalah CT. SCAN, MRI, Ultrasonografi (USG), Mesin Sinar-X, Mamografi, dan lain-lain.

Sejalan dengan perkembangan perangkat lunak dan perangkat keras, teknik analisis jaringan syaraf tiruan membutuhkan terobosan teoritis untuk mempercepat kinerja jaringan. Sebagian besar aplikasi yang telah dikembangkan menggunakan jaringan syaraf tiruan umpan maju, dengan pembobotdikoreksiyangdinamakanmetode Backpropagation. Hal ini disebabkan metode Backpropagation termasuk ke dalam pelatihan supervised (terbimbing) dan cocok untuk berbagai aplikasi, serta hasil yang dikerjakan lebih optimal dibandingkan dengan metode jaringan syaraf tiruan lainnya. Oleh karena itu, penulis membuat sistem pendeteksi penyakit osteoporosis (pengeroposan tulang) pada tangan melalui media citra ( $X$-Ray) digital, dengan menggunakan metode Backpropagation, di mana representasi cirinya dilakukan dalam ruang eigen.

Pada umumnya, untuk mendeteksi osteoporosis pada tubuh dapat dilihat dari gejala-gejala yang ditimbulkan, seperti 
nyeri pada bagian tertentu, bengkak-bengkak, dan kram atau otot sulit digerakkan. Namun, hal ini tidaklah cukup untuk membuktikannya. Oleh karena itu, diperlukan pemeriksaan lebih lanjut lagi seperti pemeriksaan radiologi untuk menilai densitas massa tulang yang sensitif, dan hasilnya berupa gambar $X$-ray yang lalu dianalisis oleh pakar Rheumatologi.

Beberapa analisis yang digunakan pakar Rheumatologi maupun spesialis penyakit, sebagai acuan untuk menentukan osteoporosis dari suatu gambar $X$-ray yaitu dengan melihat ada atau tidaknya pembengkakan, pengapuran (penipisan massa tulang), perubahan bentuk tulang yang signifikan (membengkok/memendek), atau bahkan terjadi fracture (patah tulang). Sistem analisis inilah yang kemudian penulis terapkan pada perangkat lunak deteksi osteoporosis.

\section{Permasalahan}

Permasalahan yang ada pada perancangan sistem berupa pertanyaan seperti: bagaimana mengumpulkan sejumlah citra $X$-ray yang hanya meliputi daerah tangan; bagaimana meng-crop citra tanpa harus kehilangan informasi penting di dalamnya dan tidak mengubah bentuk; bagaimana mendapatkan karakteristik osteoporosis pada tangan dengan metode PCA dan prinsip eigen; serta bagaimana menentukan nilai threshold, jumlah unit hidden layer, nilai momentum, dan nilai laju pembelajaran yang tepat, sehingga didapat hasil pengenalan yang optimal dengan waktu iterasi seminimal mungkin.

\section{Tujuan dan Manfaat}

Program aplikasi yang dibuat ini memiliki tujuan, yaitu: mempermudah orang-orang untuk melakukan pendeteksian gangguan osteoporosis dengan cara yang mudah dan murah karena hanya memerlukan gambar X-ray tangan dari radiologi; memperoleh hasil prediksi yang cepat dan optimal dalam mengenali penyakit osteoporosis; serta memperoleh persentase keberhasilan jaringan dalam mengenali penyakit, sehingga dapat diketahui tingkat kesalahannya.

\section{Ruang Lingkup}

Ruang lingkup di dalam penelitian ini dibagi menjadi beberapa bagian, yaitu: sistem, citra, dan proses.

\section{Sistem}

Secara garis besar, aplikasi deteksi osteoporosis ini tersusun atas 3 sistem, yaitu sistem pengolahan citra, representasi ciri, dan jaringan syaraf tiruan. Sistem pengolahan citra digunakan untuk mengubah kekontrasan dan format citra asli, sehingga menjadi data yang dapat di-input untuk pemrosesan berikutnya. Sistem representasi ciri, dalam hal ini dimaksudkan untuk mengambil sejumlah data (mereduksi pixel) yang dianggap mewakili karakteristik atau ciri-ciri osteoporosis yang sebenarnya dengan menggunakan teknik PCA (Principal Component Analysis), serta prinsip ruang vektor dan nilai eigen. Sistem jaringan syaraf tiruan digunakan untuk menganalisis dan mendeteksi adanya osteoporosis, sebagaimana cara kerja otak para pakar Rheumatologi dalam menganalisis.

\section{Citra}

Citra yang digunakan dalam program aplikasi ini mempunyai batasan-batasan yaitu: citra masukan merupakan citra X-Ray yang telah di-scanning; ukuran citra telah di-crop menjadi 30 x 30 pixel; format citra merupakan format yang telah diubah menjadi *.PCX; daerah citra yang diambil dan dideteksi hanya berkisar pergelangan tangan hingga jari-jari tangan; serta prediksi pada citra hanya terdiri dari 2 kategori, yaitu citra normal (bernilai '0') atau citra osteoporosis (bernilai '1').

\section{Proses}

Ruang lingkup proses keseluruhan pada penelitian ini, yaitu: membuka file citra tangan yang berformat *.PCX; mengubah warna citra ke bentuk greyscale; memisahkan daerah objek dengan background menggunakan thresholding; mengambil nilai intensitas keabuan (greylevel) untuk setiap pixel citra; normalisasi nilai greylevel; mereduksi jumlah pixel di dalam ruang eigen; menjalankan proses jaringan syaraf tiruan Backpropagation; training jaringan hingga error, yang didapat lebih kecil dari batas toleransi atau telah melebihi jumlah iterasi yang dimasukkan; menyimpan bobotbobot akhir yang bersesuaian; serta testing atau mapping jaringan, dengan memasukkan pola baru ataupun pola yang telah dilatih.

\section{Landasan Teori}

\section{Pengolahan Citra}

Pengolahan citra merupakan suatu sistem di mana proses dilakukan dengan masukan berupa citra, dan menghasilkan citra pula dengan kualitas yang lebih baik. Pada penelitian ini, citra yang digunakan adalah citra $X$-ray bergambar rangka tulang tangan, di mana setelah melalui proses scan akan menghasilkan citra digital (*.PCX). Citra digital adalah citra yang didefinisikan sebagai fungsi $f(x, y)$ di mana $\mathrm{x}$ menyatakan nomor baris, y menyatakan nomor kolom, dan f menyatakan nilai derajat keabuan (greylevel) pada citra.

\section{RGB}

Dasar dari pengolahan citra adalah pengolahan warna RGB pada posisi tertentu. Dalam pengolahan citra, warna direpresentasikan dengan nilai hexadesimal 0x00000000 sampai dengan 0x00ffffff.

\section{Grayscale}

Dalam pengolahan citra, pengubahan warna citra menjadi citra grayscale digunakan untuk menyederhanakan model citra. Citra berwarna memiliki 3 komposisi warna, yaitu red (R), green $(\mathrm{G})$, dan blue (B). Untuk mendapatkan citra grayscale, maka 3 komponen tersebut dirata-rata. Dalam citra ini, tidak ada lagi warna; yang ada hanya derajat keabuan.

\section{Thresholding}

Selain digunakan untuk mengatur derajat keabuan yang ada pada citra, thresholding juga untuk memisahkan bagian citra yang sesuai dengan objek (foreground) dan latar belakangnya (background), serta mengkonversi data citra menjadi data biner (binerisasi), dengan tujuan agar proses selanjutnya menjadi mudah.

Setiap citra meskipun mengandung objek yang sama, tentunya memiliki karakteristik yang berbeda dalam sifat-sifat pencahayaannya. Hal ini menyebabkan sulitnya menentukan nilai threshold yang cocok untuk diterapkan ke semua kondisi citra. Oleh karena setiap citra mempunyai nilai threshold masing-masing, maka dapat dilakukan pembelajaran berupa pengetahuan sifat-sifat dari masingmasing citra yang akan diproses sebelum menentukan nilai threshold yang cocok. Dengan demikian, setelah melalui trial and error akan ditemukan nilai threshold, yang kurang lebih cocok diterapkan untuk semua citra. 


\section{Normalisasi}

Normalisasi digunakan untuk mengecilkan range data gambar, yang dalam hal ini berupa range piksel. Normalisasi data dapat dilakukan dengan berbagai cara, diantaranya dengan cara mentransformasi ke dalam interval tertentu. Jika fungsi aktivasi yang akan digunakan berupa fungsi aktivasi sigmoid biner, data harus ditransformasi atau normalisasi ke interval $[0,1]$. Tapi, akan lebih baik jika ditransformasikan ke interval yang lebih kecil, yaitu interval [0.1, 0.9]. Hal ini dikarenakan fungsi sigmoid biner merupakan fungsi asimtotik yang nilainya tidak pernah mencapai 0 ataupun 1 .

$$
\mathrm{x}^{\prime}=\frac{0.8(\mathrm{x}-\mathrm{a})}{\mathrm{b}-\mathrm{a}}+0.1
$$

Di mana a adalah data minimum dan $b$ adalah data maksimum. Jika fungsi aktivasi yang digunakan adalah fungsi sigmoid bipolar, data dinormalisasi ke interval $[-1,1]$ terlebih dulu.

\section{Rheumatologi}

Tulang merupakan bagian terpenting dari tubuh manusia dan mahluk hidup lainnya. Tulang terbentuk dari matrik dan garam-garam non organik berupa kalsium, fosfat, dan dilapisi membran atau ligamen berserat di sekitarnya untuk melicinkan pergerakan sendi. Tubuh manusia, normalnya tersusun atas 206 tulang yang memberikan struktur dan bentuk. Tulang-tulang ini berfungsi untuk melindungi organ-organ dalam yang vital dan rawan, sebagai tempat penyimpanan mineral-mineral, dan tempat pembentukan selsel darah.

\section{Rheumatologi dan Landasan Ilmiah Anatomi Tangan}

Rheumatologi adalah salah satu cabang ilmu penyakit dalam yang berkonsentrasi pada diagnosis dan terapi penyakit rematik. Salah satu metode diagnosis yang digunakan para ahli Rheumatologi adalah melalui sinar- $X$ atau radiograf untuk menghasilkan gambar medikal ( $X$-ray atau rontgen). Tulang pada bagian sendi pergelangan hingga jari-jari tangan merupakan salah satu daerah yang dapat dijadikan gambaran kondisi ada atau tidaknya tanda-tanda penyakit osteoporosis, karena seringkali rasa nyeri dan pembengkakan yang terjadi pada tangan (Gambar 1) terletak pada sekitar daerah tersebut.

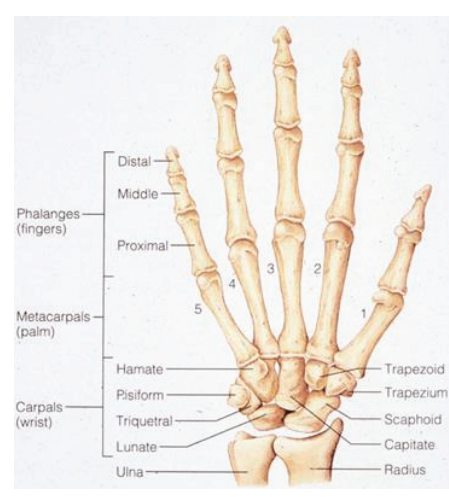

Gambar 1 Struktur Rangka Tangan Manusia

\section{Osteoporosis}

Osteoporosis adalah penyakit metabolisme tulang, di mana tulang-tulang menjadi rapuh dan mudah patah akibat pengurangan massa dan kemunduran mikroarsitektur tulang. Pemeriksaan radiologi digunakan untuk menilai densitas massa tulang yang sudah mengalami pengurangan sebesar 50 persen. Gambaran radiologi yang khas pada osteoporosis adalah penipisan korteks dan daerah trabekular (tulang bagian dalam dan berongga). Pada tulang tangan (Gambar 2), daerah osteoporosis banyak ditemukan di sekitar falang medial jari II dan III, dan juga pada tulang metacarpal.
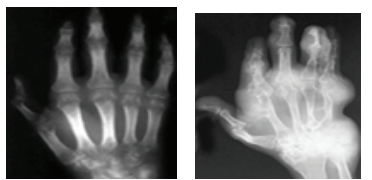

Gambar 2 X-ray Tangan yang Positif Menderita Osteoporosis

\section{Jaringan Syaraf Tiruan}

Jaringan Saraf Tiruan (JST) didefinisikan sebagai suatu sistem pemrosesan informasi yang mempunyai karakteristik menyerupai jaringan saraf manusia (Gambar 3). Jaringan saraf tercipta sebagai suatu generalisasi model matematis dari pemahaman manusia.

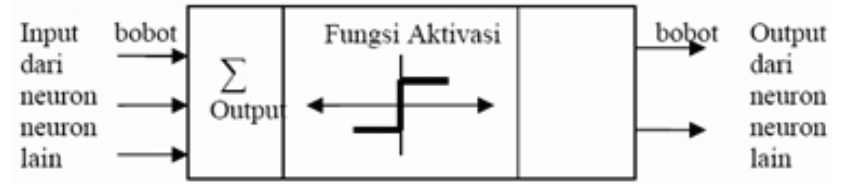

Gambar 3 Struktur Neuron Jaringan Syaraf Tiruan

Secara umum, proses pembelajaran JST dapat dikategorikan menjadi 2 jenis proses, yaitu: supervised training (pelatihan terbimbing), yaitu tiap pola input memiliki pola target; dan unsupervised training (pelatihan tidak terbimbing). Pada pelatihan ini, vektor target tidak dibutuhkan untuk keluarannya, sehingga tidak ada perbandingan untuk menentukan respon yang ideal.

\section{Jaringan Syaraf Tiruan Backpropagation}

Metode Backpropagation atau disebut juga propagasi balik, pertama kali dirumuskan oleh Werbos dan dipopulerkan oleh Rumelhart bersama McClelland, di mana algoritma ini termasuk metode pelatihan terbimbing (supervised) dan didesain untuk operasi pada jaringan syaraf tiruan feed forward multi-layer. Arsitektur dari JST Backpropagation terdiri dari 3 bagian, yang meliputi masukan, lapis tersembunyi, dan keluaran (Gambar 4).

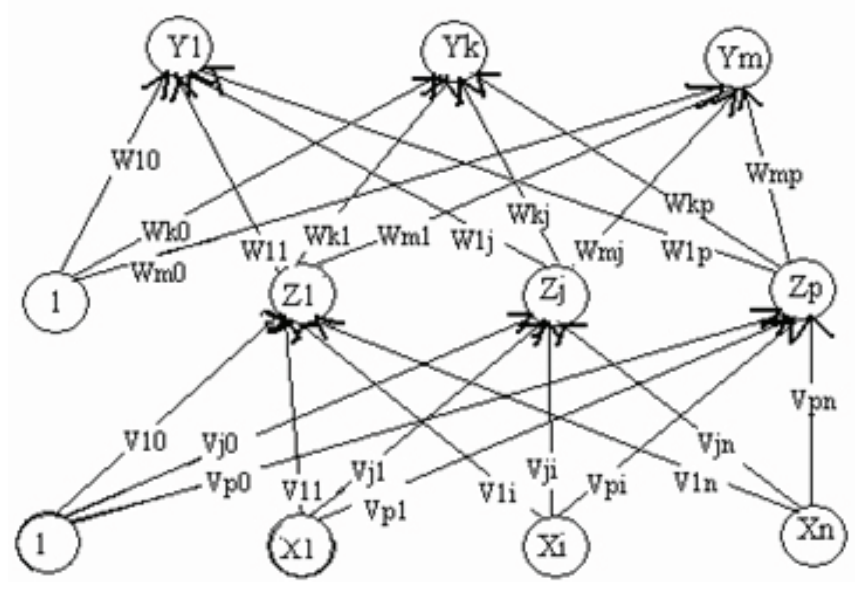

Gambar 4 Struktur JST Backpropagation [7] 


\section{Pemilihan Bobot dan Bias Awal}

Pada tahun 1990, Nguyen dan Widrow mengusulkan cara membuat inisialisasi bobot dan bias ke unit tersembunyi, sehingga menghasilkan iterasi lebih cepat. Algoritma inisialisasi Nguyen Widrow adalah sebagai berikut. Pertama, inisialisasi semua bobot $\left(\mathrm{v}_{\mathrm{ij}}\right.$ ( lama $\left.)\right)$ dengan bilangan acak dalam interval $[-0.5,0.5]$. Kedua, hitung $\|\mathrm{vj}\|={\sqrt{\mathrm{v}_{\mathrm{j} 1}}}^{2}+\mathrm{v}_{\mathrm{j} 2}{ }^{2}$. $+\ldots+\mathrm{v}^{2}{ }^{2}$....(2.2). Ketiga, bobot yang dipakai sebagai inisialisasi $=\mathrm{v}_{\mathrm{ji}}=\left[\beta . \mathrm{v}_{\mathrm{ji}}\right.$ (lama) $] /\left\|\mathrm{v}_{\mathrm{j}}\right\|$....(2.3). Keempat, bias yang dipakai sebagai inisialisasi $=\mathrm{v}_{\mathrm{j} 0}=$ bilangan acak antara $-\beta$ dan $\beta$; di mana $\mathrm{n}$ adalah jumlah unit masukan, $\mathrm{p}$ adalah jumlah unit tersembunyi, dan $\beta$ adalah faktor skala sebesar $0.7^{\mathrm{n}} \sqrt{\mathrm{p}}$......(2.4)

\section{Fungsi Aktivasi}

Dalam Backpropagation, fungsi aktivasi yang dipakai harus memenuhi beberapa syarat yaitu: kontinu, terdeferensial dengan mudah, dan merupakan fungsi yang tidak turun. Salah satunya adalah fungsi sigmoid biner dengan range $[0,1]$ :

$$
f(x)=\frac{1}{1+e^{-x}}
$$

\section{Pelatihan Standar Backpropagation}

Algoritma pelatihan Backpropagation terdiri dari 2 tahapan, feed forward dan Backpropagation dari galatnya, yaitu: langkah 0 , pemberian inisialisasi penimbang (diberi nilai kecil secara acak); langkah 1, ulangi langkah 2 hingga 9 sampai kondisi akhir iterasi dipenuhi; dan langkah 2, untuk masing-masing pasangan data pelatihan lakukan langkah 3 hingga 8.

Umpan maju (feed forward), terdiri dari: langkah 3 , masing-masing unit masukan $\left(X_{i}, i=1, \ldots n\right)$ menerima sinyal masukan Xi dan sinyal tersebut disebarkan ke unit-unit bagian berikutnya (unit-unit lapis tersembunyi); langkah 4 , masing-masing unit dilapis tersembunyi, dikalikan dengan penimbang dan dijumlahkan, serta ditambah dengan biasnya; dirumuskan dengan $Z Z_{-} i n_{j}=V_{j 0}+\sum X_{i} V_{j i} \ldots \ldots . .(2.6)$. Kemudian dihitung sesuai dengan fungsi pengaktif yang digunakan adalah: $Z_{j}=f\left(Z_{-}\right.$in $)$....................(2.7). Bila yang digunakan adalah fungsi sigmoid maka bentuk fungsi tersebut adalah:

$$
Z_{j}=\frac{1}{1+\exp ^{\left(z_{-} i j_{j}\right)}} \text {.............(2.8). Sinyal keluaran dari fungsi }
$$

pengaktif tersebut dikirim ke semua unit di lapis keluaran; berikutnya adalah langkah 5, masing-masing unit keluaran (Yk, $\mathrm{k}=1,2,3 \ldots \mathrm{m})$ dikalikan dengan penimbang dan dijumlahkan serta ditambah dengan biasnya. Rumusnya adalah $Y_{i} i n_{k}=W_{k 0}+\sum Z_{j} W_{k j}$...............(2.9). Kemudian dihitung kembali sesuai dengan fungsi pengaktif sebagai $y_{k}=$ $f\left(y_{-} i_{k}\right) \ldots \ldots \ldots \ldots \ldots . . .(2.10)$

Backpropagasi (Backpropagation) dan Galatnya, terdiri dari: langkah 6 , masing-masing unit keluaran $\left(\mathrm{Y}_{\mathrm{k}}\right.$, $\mathrm{k}=1, \ldots, \mathrm{m})$ menerima pola target sesuai dengan pola masukan saat pelatihan/training dan dihitung galatnya dengan rumus $\delta_{k}=\left(t_{k}-y_{k}\right) f\left(y_{-} i n_{k}\right) \ldots \ldots \ldots .(2.11)$. Karena $f\left(y_{-} i n_{k}\right)=y_{k}$ menggunakan fungsi sigmoid, maka $f\left(y_{-} i n_{k}\right)=$ $f(y$ in $)(1-f(y$ in $))=y_{t}\left(1-y_{t}\right)$..............(2.12). Menghitung perbaikan penimbang (kemudian untuk memperbaiki $\mathrm{W}_{\mathrm{kj}}$ ) dengan rumus $\Delta W_{k j}=\alpha \cdot \delta_{k} \cdot Z_{j} \ldots \ldots \ldots \ldots \ldots . .(2.13)$. Sedangkan untuk menghitung perbaikan korelasi dengan rumus $\Delta W_{k 0}=$ $\alpha . \delta_{k} \ldots \ldots \ldots \ldots . . . .(2.14)$. Dan menggunakan nilai delta $\left(\delta_{k}\right)$ pada semua unit lapis sebelumnya; berikutnya adalah langkah 7, masing-masing penimbang yang menghubungkan unit-unit lapis keluaran dengan unit-unit pada lapis tersembunyi $\left(Z_{j}, j\right.$ $=1, \ldots$ p) dikalikan dengan delta $\left(\delta_{k}\right)$ dan dijumlahkan sebagai masukan ke unit-unit lapis berikutnya dengan rumus $\delta$ in $n_{j}=\sum$ $\delta_{k} W_{k j} \ldots \ldots \ldots \ldots . . . . .(2.15)$. Selanjutnya dikalikan dengan turunan dari fungsi pengaktifnya untuk menghitung galat dengan rumus $\delta_{\mathrm{j}}=\delta_{-}$in $_{\mathrm{j}} f\left(y_{-} i n_{j}\right) \ldots \ldots \ldots \ldots . .(2.16)$. Langkah selanjutnya untuk menghitung perbaikan penimbang (digunakan untuk memperbaiki $\mathrm{V}_{\mathrm{ji}}$ ) dengan rumus $\Delta \mathrm{V}_{\mathrm{ji},} \alpha . \delta \mathrm{X}_{\mathrm{i}} \ldots \ldots \ldots(2.17)$. Kemudian menghitung perbaikan bias (untuk memperbaiki $\mathrm{V}_{\mathrm{j} 0}$ ) dengan rumus $\Delta \mathrm{V}_{\mathrm{j} 0=} \alpha . \delta \ldots \ldots \ldots .(2.18)$.

Memperbaiki penimbang dan bias, terdiri dari: langkah 8 , masing-masing keluaran unit $\left(\mathrm{Y}_{\mathrm{k}}, \mathrm{k}=1, \ldots, \mathrm{m}\right)$ diperbaiki bias dan penimbangnya $(\mathrm{j}=0, \ldots ., \mathrm{p})$ dengan rumus $\mathrm{W}_{\mathrm{kj}}($ baru $)=\mathrm{W}_{\mathrm{kj}}($ lama $)+\alpha \cdot \delta_{k} . Z_{j} \quad \ldots \ldots \ldots . .(2.19)$. Atau apabila parameter momentum $(\mu)$ digunakan menjadi:

$\mathrm{W}_{\mathrm{kj}}($ baru $)=\mathrm{W}_{\mathrm{kj}}($ lama $)+\alpha \cdot \delta_{k} \cdot Z_{j}+\left(\mu\left(\mathrm{W}_{\mathrm{kj}}\right.\right.$ (lama $)-\mathrm{W}_{\mathrm{kj}}($ lama -1) $)$ ) ........(2.20). Masing-masing unit tersembunyi $\left(Z_{\mathrm{ij}}^{\mathrm{kj}} \mathrm{j}=1\right.$, ...,p) diperbaiki bias dan penimbangnya $(\mathrm{j}=1, \ldots \mathrm{n})$ dengan rumus $\mathrm{V}_{\mathrm{ji}}($ baru $)=\mathrm{V}_{\mathrm{jij}}($ lama $)+\alpha . \delta_{J} \mathrm{X}_{\mathrm{i}}$.............(2.21). Atau apabila parameter momentum digunakan menjadi: $\mathrm{V}_{\mathrm{ji}}$ (baru)

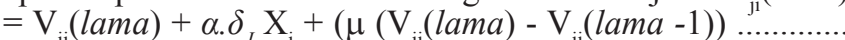
$(2.22)$; berikutnya adalah langkah 9 , yakni dengan uji kondisi pemberhentian (akhir iterasi).

\section{Parameter Pelatihan}

Beberapa parameter JST yang digunakan yaitu: inisialisasi penimbang, jenis adaptasi penimbang, learning rate, momentum, dan penentuan jumlah lapis tersembunyi.

\section{Proses Pelatihan}

Untuk menentukan jumlah pelatihan, digunakan 2 macam stopping kriteria yaitu: berdasarkan jumlah pelatihan yang dilakukan (epochs), misalnya pelatihan akan dihentikan setelah dilakukan sejumlah pelatihan; serta berdasarkan Galat Mean Square Error (MSE), maka proses pelatihan akan terus dilakukan sampai error-nya menjadi lebih kecil dari batas toleransi. Perhitungan MSE yakni:

$$
\text { MSE }=\frac{\sum(\text { target }- \text { output })^{2}}{\text { jumlah pola }}
$$

\section{Proses Mapping}

Proses mapping dilakukan dengan menjalankan prosedurfeed forward dengan penimbang yang telah disimpan sebelumnya (dilakukan load data penimbang dari file). Hasil keluaran dari JST merupakan hasil dari proses mapping. Sehingga dengan proses mapping ini, dapat dilakukan proses identifikasi, sekaligus didapatkan diagnosa dari hasil $X$-ray.

\section{Nilai Eigen dan Vektor Eigen}

Untuk mencari nilai eigen matriks A yang berukuran $\mathrm{n} \mathrm{x} \mathrm{n}$, maka kita menuliskan kembali $\mathrm{Ax}=\lambda \mathrm{x}$ sebagai: $\mathrm{Ax}=$ ג.I.x ................ (2.24).

Secara ekuivalen, vektor eigen yang bersesuaian dengan $\lambda$ adalah vektor tak nol dalam ruang pemecahan dari $(\lambda \mathrm{I}-\mathrm{A}) \mathrm{x}=0$. Dan ruang pemecahan ini dinamakan sebagai ruang eigen (eigen space) dari A yang bersesuaian dengan $\lambda$.

\section{Teknik Principal Component Analysis (PCA)}

Metode PCA atau Principal Component Analysis pertama kali diajukan pada 1933 oleh Hotteling dengan tujuan untuk mengurangi dimensi sebuah ruang yang direpresentasikan oleh variabel statistik $x_{1}, x_{2}, \ldots . x_{n}$.

Langkah-langkah untuk mereduksi dimensi pada metode PCA yaitu sebagai berikut. Pertama, jika terdapat himpunan $\mathrm{p}$ buah, citra pelatihan yang dapat direpresentasikan ke dalam $\left[\mathrm{x}_{1}, \mathrm{x}_{2}, \ldots \mathrm{x}\right]$, dengan dimensi tiap citra adalah $\mathrm{q}$ (baris x kolom), maka dapat dibentuk matriks data pelatihan Y dengan orientasi vektor kolom sebagai berikut:

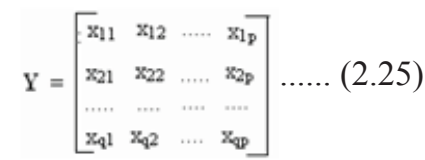


Dengan xij menunjukkan nilai intensitas dari piksel citra pelatihan ke-j variabel (dimensi) $\mathrm{ke}-\mathrm{i}$.

Kedua, mencari rata-rata vektor citra dengan rumus $\mu_{\mathrm{i}}=\frac{1}{\mathrm{p}} \sum \mathrm{Z}_{\mathrm{ip}}$ (2.26), di mana $Z$ adalah total piksel citra ke-i dari citra pelatihan ke $-1 \mathrm{~s} / \mathrm{d} \mathrm{p}$. Sehingga dapat dibentuk sebuah citra matriks rata-rata $\mu=\left[\begin{array}{llll}\mu_{1} & \mu_{2} & \ldots & \mu_{\mathrm{q}}\end{array}\right]$. Ketiga, kemudian hitung selisih vektor citra dengan rata-rata vektor citra dengan rumus $\mathrm{A}=\mathrm{Y}-\mu \ldots \ldots \ldots \ldots \ldots . . .(2.27)$. Keempat, dari matriks A diatas dapat dihitung matriks total scatter berupa matriks kovarian (real, simetrik): $S=\mathrm{AA}^{\mathrm{T}}$ (berordo q $\mathrm{x} \mathrm{q}$ )...... (2.28). Kelima, cari eigen vektor $\mathrm{V}$ dan nilai eigen $\mathrm{D}$ dari matriks $\mathrm{S}$ dan urutkan eigen vektor berdasarkan nilai eigen yang terbesar. Keenam, tentukan dimensi ruang ciri dengan rumus

$$
\mathrm{m}=\min \mathrm{q}\left[\begin{array}{l}
\frac{p}{\sum} D_{j} \\
\sum D_{j} D_{j}
\end{array}>\theta\right] \ldots \ldots \ldots \ldots . . . . .(2.29) . \text { Ketujuh, reduksi vektor }
$$

eigen menjadi vektor eigen $\mathrm{V}$ ' (eigenspace) sesuai dengan nilai $\mathrm{m}$. Kedelapan, transformasi vektor citra menjadi vektor ciri dengan rumus $\mathrm{Y}^{\prime}=\mathrm{V}^{\mathrm{T}}$.A............. (2.30), di mana kolom untuk citra, dan baris untuk piksel-piksel.

\section{Analisis dan Perancangan Program}

Gambar 5 merupakan gambar diagram Use-Case sistem deteksi penyakit pengeroposan tulang. Sedangkan pada Gambar 6, dapat dilihat gambar diagram alir perangkat lunak.

\section{Diagram Alir Perangkat Lunak}

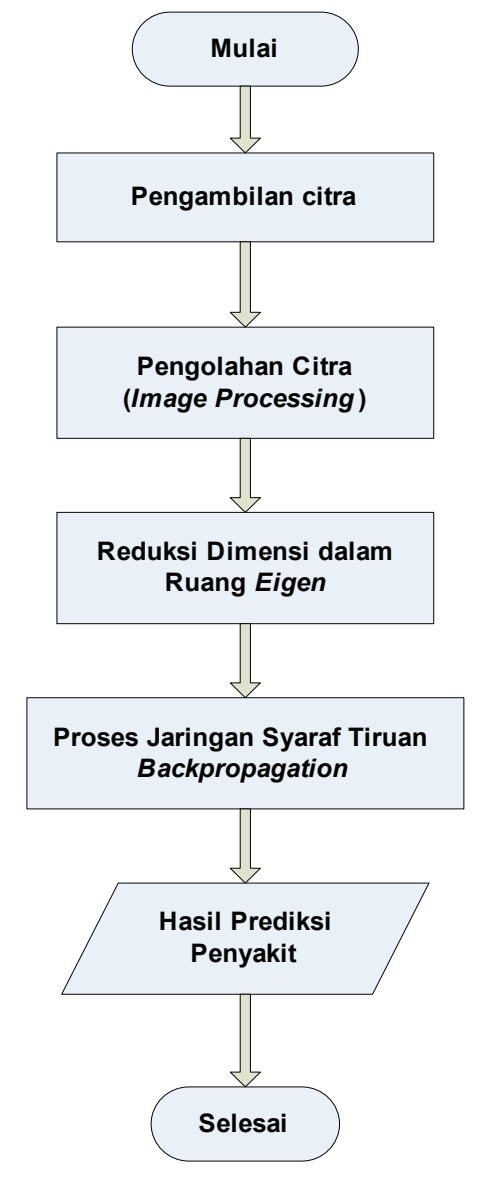

Gambar 6 Diagram Alir Perangkat Lunak

\section{Konversi ke Grayscale}

Algoritma dari pengkonversian RGB ke grayscale

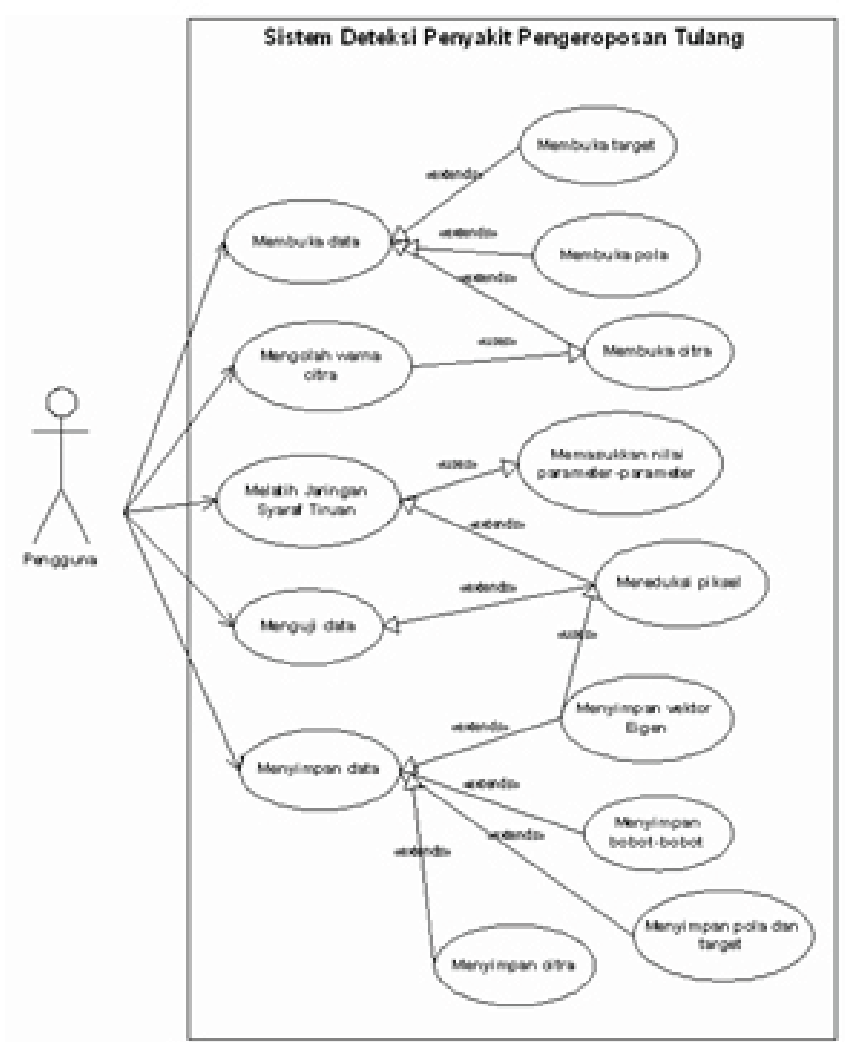

Gambar 5 Diagram Use-Case Sistem Deteksi Penyakit Pengeroposan Tulang

adalah sebagai berikut:

Picture. Height $=$ tinggi citra

Picture. Width = lebar citra

For $\mathrm{j}=1$ to picture.Height

$$
\text { For } \mathrm{i}=1 \text { to picture. Width }
$$

$r=$ Picture.Pixel $[i, j]$

$\mathrm{g}=$ Picture.Pixel $[\mathrm{i}, \mathrm{j}]$

$\mathrm{b}=$ Picture.Pixel[ $[\mathrm{i}, \mathrm{j}]$

$/ /$ mencari nilai grayscale

gray $=(r+g+b) / 3$

$$
\text { Next } \mathrm{i}
$$$$
\text { Picture.Pixel }[i, j]=\text { gray }
$$

Next j

\section{Thresholding}

Algoritma dari threshoding yaitu sebagai berikut:

picture.Height = tinggi citra

picture. Width = lebar citra

threshold $=80 \quad / /$ misalnya nilai $=80$

For $\mathrm{j}=1$ to picture.Height

For $i=1$ to picture. Width

gray $=$ Picture.Pixel $[i, j]$

//seleksi

If gray $>$ threshold Then

Else

$$
\text { gray }=\text { gray } / / \text { grayscale tetap }
$$

End If

$$
\text { gray }=0 / / \text { grayscale bernilai nol }
$$

Picture.Pixel $[\mathrm{i}, \mathrm{j}]=$ gray

Next j

Next i

\section{Normalisasi Data}

Normalisasi atau transformasi data pada program ini dilakukan ke interval $[0.1,0.9]$ yang dalam perhitungan mendekati interval sebenarnya yaitu $[0,1]$. 
Algoritmanya sebagai berikut :

picture. Height $=$ tinggi citra

picture. Width = lebar citra

For $\mathrm{j}=1$ to picture.Height

For $i=1$ to picture. Width

grayscale $=$ Picture.Pixel $[i, j]$

//Normalisasi

Trans $=((0.8 *($ grayscale -0$)) /(255-0))+0.1$

//menyimpan hasil ke array

index $[i, j]=$ Trans

Next $i$

Next j

\section{Mereduksi Jumlah Piksel}

Pada tahap ini, piksel-piksel setiap citra yang dikumpulkan dalam sebuah matriks $\left(\mathrm{N}_{\text {to }} \times \mathrm{M}_{\text {dta }}\right)$ akan mengalami pengurangan sejumlah baris atau sejumlah kolom tertentu, sesuai dengan nilai eigen yang paling rendah.

Di dalam program ini, pengaplikasian metode PCA digunakan bersamaan dengan module KLT yang telah ada untuk mengambil karakteristik dari input data-data yang diberikan dalam mencari nilai dan vektor eigen.

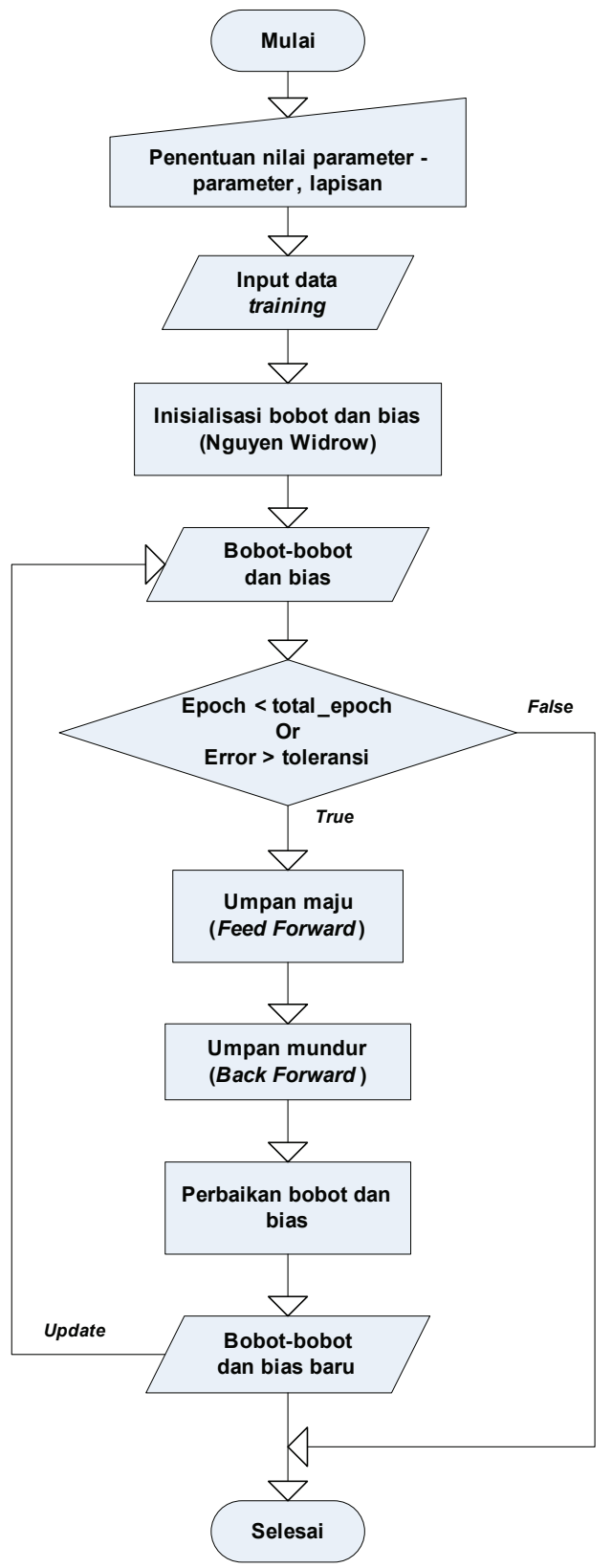

Gambar 7 Diagram Alir Proses Training JST Backpropagation

\section{Proses Training Jaringan Syaraf Tiruan}

Pada perancangan program sistem deteksi penyakit pengeroposan tulang ini, konfigurasi jaringan syaraf yang digunakan adalah: metodenya adalah Backpropagation; jumlah lapis sebanayak 3 lapis, terdiri atas satu lapis masukan, satu lapis tersembunyi, dan satu lapis keluaran; jumlah unit output sebanyak satu unit; fungsi aktivasinya adalah fungsi sigmoid biner; jenis training adalah pelatihan terbimbing (supervised training); threshold sebesar 0,55; momentum dari 0.1 sampai 0.9 ; learning rate dari 0.1 sampai 0.9; unit target sebanyak satu unit; tolerance sebesar 0.001 hingga 0.002 ; iterasi (epoch) sebesar 10000; metode inisialisasi bobot dan bias awalnya adalah dengan metode Nguyen Widrow; serta jenis adaptasi bobotnya adalah dengan adaptasi biasa (incremental updating). Diagram alir proses training JST Backpropagation dapat dilihat pada Gambar 7.

\section{Proses Mapping}

Pada proses mapping atau pengujian ini, algoritma Backpropagation yang dijalankan hanyalah pada bagian proses feedfoward (umpan maju) saja, yaitu dengan memasukkan bobot-bobot yang sesuai dan telah disimpan di harddisk dari hasil proses training ke unit-unit input hingga menghasilkan keluaran. Untuk flowchart proses testing JST Backpropagation dapat dilihat pada Gambar 8.

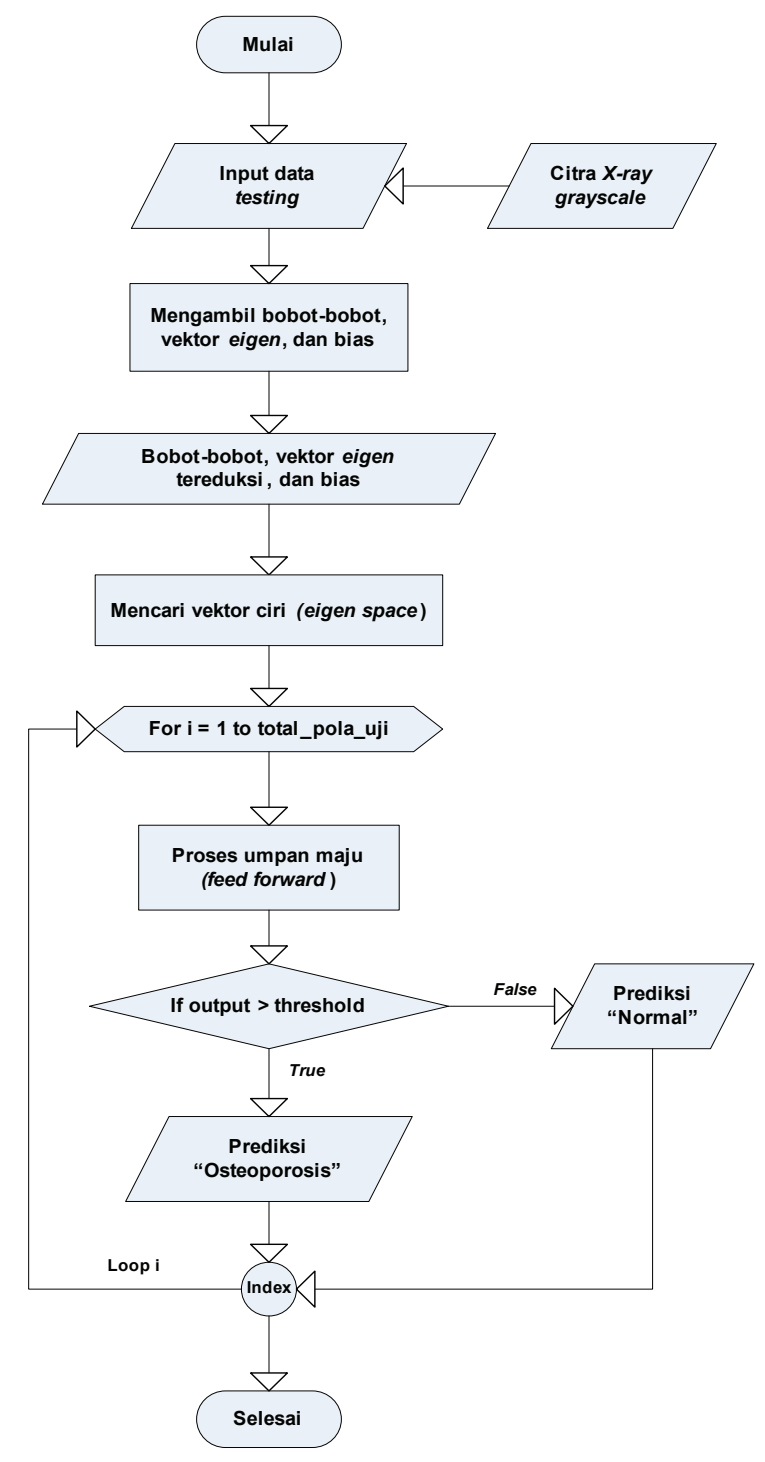

Gambar 8 Flowchart Proses Testing JST Backpropagation 


\section{Implementasi dan Hasil Uji Coba Program}

Pengujian citra pada proses mapping, dalam hal ini dilakukan dengan jumlah perbandingan 25:75; yaitu dari keempatpuluh citra sampel, 10 sampel digunakan untuk proses training dan 30 sampel lainnya untuk proses mapping.

\section{Pengambilan Citra Pengujian}

Citra-citra $X$-ray yang akan diujicobakan pada proses training dan testing jaringan syaraf tiruan merupakan citra yang sebelumnya telah melalui proses scanning dan cropping. Hasilnya yaitu akan berupa citra $X$-ray digital berformat PCX berukuran 30x30 piksel.

\section{Pengujian Perangkat Lunak}

Langkah-langkah yang dilakukan adalah: dengan mengkonversi warna ke grayscale (Gambar 9 dan 10); berikutnya adalah dengan thresholding (Tabel 1). Berdasarkan rata-rata uji coba (trial and error) yang telah dilakukan, nilai threshold yang paling sesuai untuk digunakan bernilai antara 60 hingga 80 . Hal ini dikarenakan nilai threshold 60 hingga 80 tidak berlebihan dalam menghilangkan piksel berintensitas rendah dan sudah tidak meninggalkan daerah background pada citra. Dengan demikian, dari interval nilai threshold 60 hingga 80 dipilihlah nilai threshold tetap secara subjektif, yaitu 80 untuk keseluruhan thresholding. Jadi, jika citra dengan derajat keabuan kurang dari 80, maka derajat keabuan diubah menjadi 0 (background). Jika sebaliknya, derajat keabuan akan bernilai tetap (foreground).

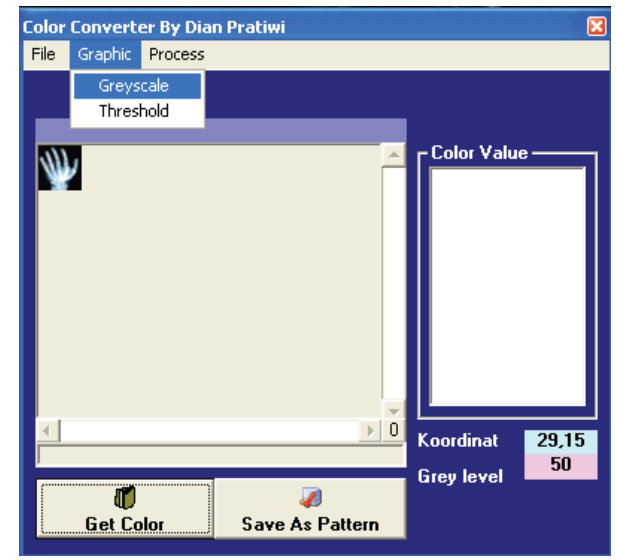

Gambar 9 Form Color Converter

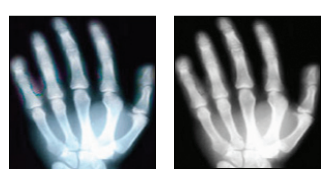

Gambar 10 Citra Hasil Proses Grayscale; Citra X-ray Sebelum Diproses (Kiri), Citra $X$-ray Setelah Diproses (Kanan).

\section{Mengambil Piksel Citra}

Langkah-langkah dari tahap ini yaitu dengan mengambil dan menampilkan grayscale tiap piksel (Gambar 11); serta menyimpan grayscale sebagai pola (Gambar 12). Pada tahap ini, graylevel yang telah ditampilkan akan dijadikan sebagai pola (satu pola satu citra) setelah melalui proses normalisasi, di mana setiap polanya akan memiliki sebuah target ('1' atau '0') yang dimasukkan.
Uji Coba Nilai Threshold
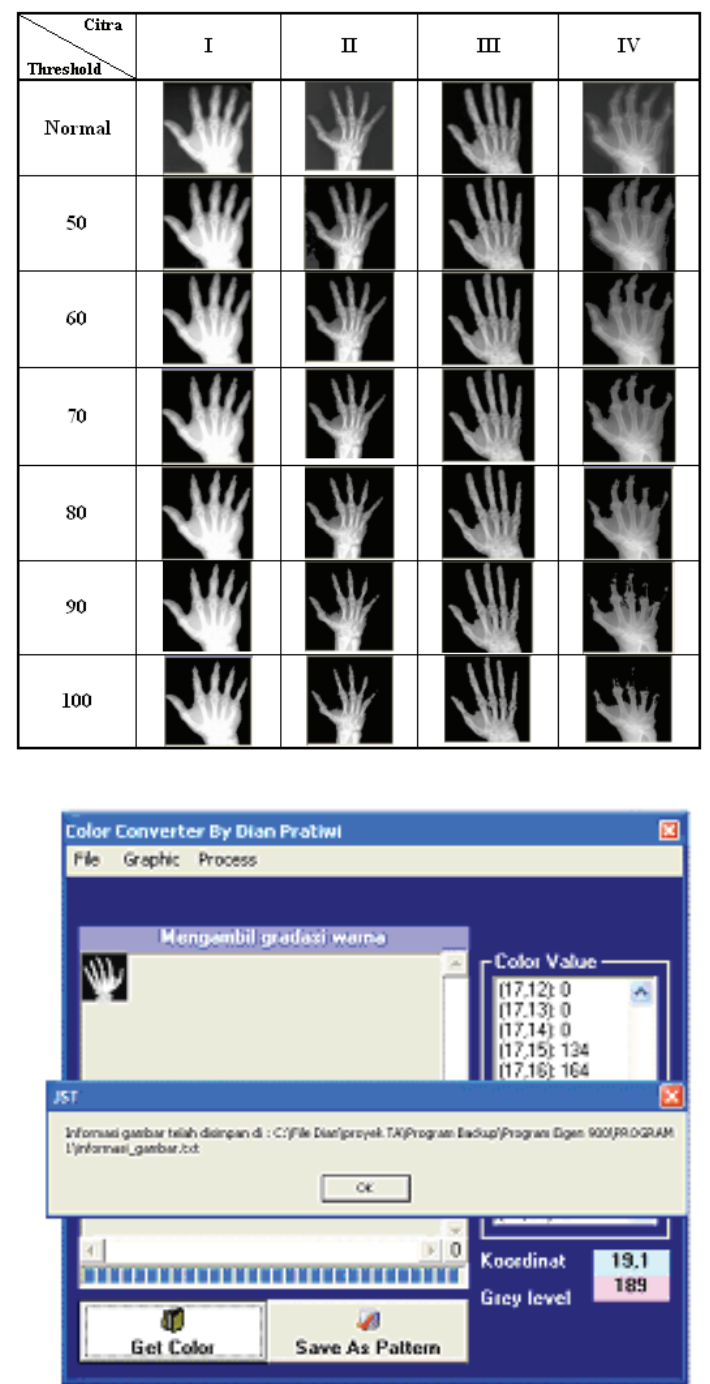

Gambar 11 Form Color Converter;

Grayscale Ditampilkan dan Disimpan.

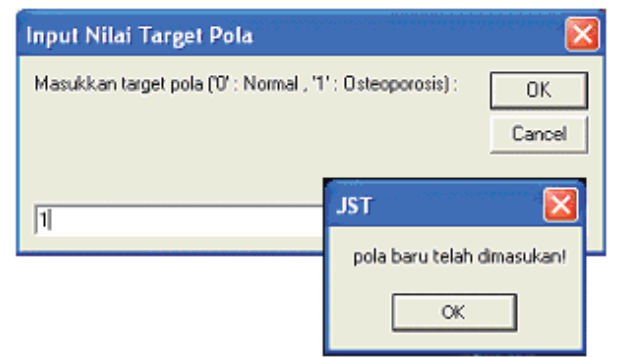

Gambar 12 Tampilan Input Box Nilai Target dan Konfirmasinya

\section{Mereduksi Dimensi Citra}

Pada proses ini, jumlah piksel yang terkandung pada citra direduksi (dikurangi) dengan metode PCA dan prinsip ruang eigen, di mana hasil dari reduksinya berupa vektor ciri yang akan dipergunakan sebagai input data proses training jaringan syaraf tiruan, dan vektor eigen tereduksi yang dapat disimpan sebagai file teks (*.txt) untuk digunakan dalam proses mapping (Gambar 13). 


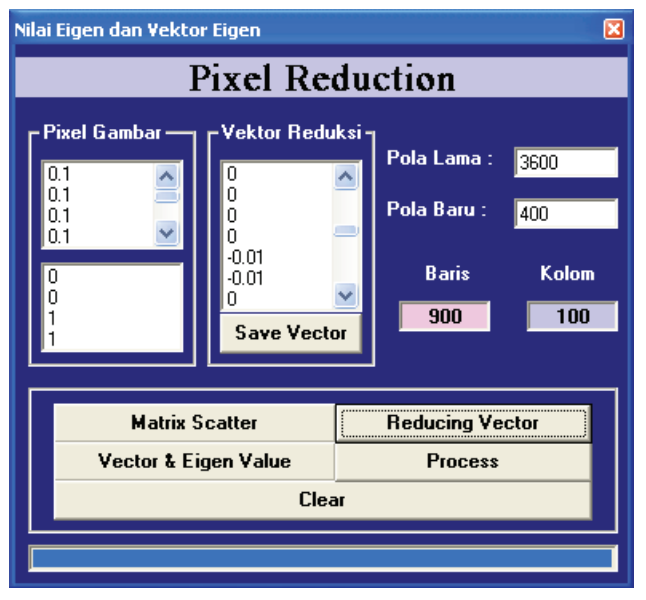

Gambar 13 Form Pixel Reduction

\section{Memulai Training JST Backpropagation}

Pada proses training JST di dalam program ini, nilainilai masukan diambil dari hasil proses reduksi yang berupa vektor ciri. Vektor ciri ini selanjutnya akan mengalami pelatihan jaringan berulang-ulang hingga jumlah iterasi (epoch) selesai dilakukan atau nilai galat (error) telah mencapai toleransi yang diberikan. Apabila hasil pengenalan pola pada proses ini telah mencapai 100 persen; yaitu saat galat lebih kecil dari toleransi, maka bobot-bobot dan bias dapat disimpan untuk kemudian digunakan dalam tahap mapping (Gambar 14).

Dari Tabel 2 dapat dilihat bahwa dengan memasukkan jumlah input yang semakin banyak, waktu iterasi akan semakin lama pula untuk mencapai galat minimum. Namun tidak pada percobaan 2 dan 3 , yang ternyata memberikan hasil yang baik dengan lama iterasi cukup sedikit dibandingkan dengan nomor percobaan lainnya. Hal ini dapat dikarenakan kesesuaiannya nilai-nilai parameter yang diberikan terhadap banyaknya unit input, sehingga menghasilkan pengenalan pola yang lebih optimal. Oleh karena itu, penyusun menetapkan mengambil jumlah unit input training hanya sebanyak 500 dan 600 unit dari 10 citra (pola) untuk dibandingkan kembali dengan memasukan nilai-nilai parameter yang berbeda, dan kemudian dilatih untuk mengetahui hasil pengenalan yang paling baik

Berdasarkan Tabel 3 sampai 5 yang merupakan hasil pengujian, proses training akan menghasilkan pengenalan pola yang baik hingga 100 persen dan lama iterasi yang cukup singkat apabila digunakan nilai parameter sebesar 0.7 dan 0.4 (Tabel 5 percobaan 4 ) serta 0.7 dan 0.5 (Tabel 4

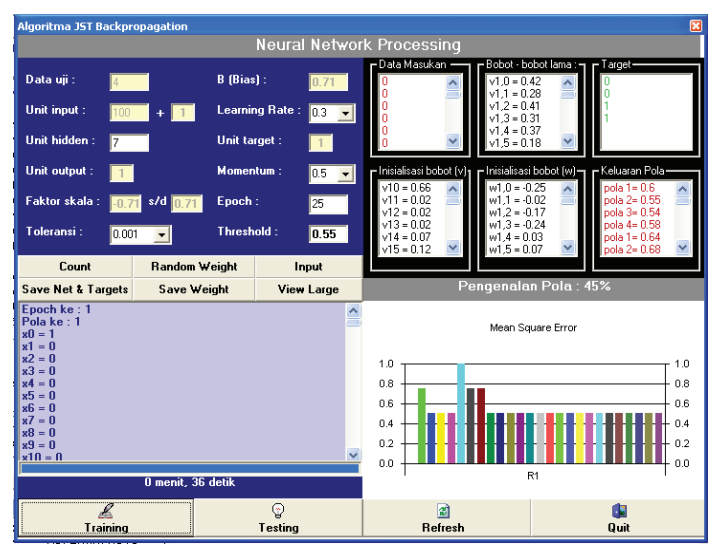

Gambar 14 Form Training JST Backpropagation percobaan 6) pada nilai learning rate dan momentum. Bobotbobot dari hasil kedua pengujian ini, kemudian bisa disimpan dan dipergunakan pada tahap mapping. Namun, jika diamati lagi dari hasil kedua pengujian ini, hasil yang paling baik adalah pada pengujian dengan menggunakan nilai momentum dan learning rate sebesar 0.4 dan 0.7 , yaitu di mana lama training hanya berkisar 11 menit. Sehingga dengan demikian, bobot-bobot yang akan disimpan adalah bobot-bobot hasil dari pengujian ini.

\section{Menjalankan Testing JST (Mapping)}

Pada tahap ini (Gambar 15), bobot-bobot, vektor eigen tereduksi, maupun pola-pola citra $X$-ray yang telah disimpan akan diproses bersamaan, di mana prosesnya hanya berupa tahap feed-forward (umpan maju). Sedangkan Gambar 16 merupakan tampilan hasil prediksi dari dua puluh pola citra X-ray, di mana 25 persen dari total pola dideteksi normal atau tidak osteoporosis dan 75 persen terdeteksi osteoporosis.

\section{Hasil Uji Coba Testing Perangkat Lunak}

Pada Tabel 6 ditunjukkan bahwa hasil dari pengujian atau mapping pola-pola yang sebelumnya telah dilatih akan memberikan persentase kebenaran 100 persen dalam mengenali pola. Hal ini dikarenakan bobot-bobot yang disimpan dan digunakan merupakan hasil pelatihan yang sama dengan pola-pola tersebut. Untuk data gambar selengkapnya dapat dilihat pada lampiran 2 .

Pada Tabel 8 dapat juga dilihat hasil pengujian polapola citra $X$-ray yang belum dilatih. Dari tabel ini dapat diketahui juga bahwa pengenalan pola masih belum optimal, di mana masih terdapat kesalahan pendeteksian sejumlah 8 pola $X$-ray (27 persen) dari 30 pola non-thresholding dan 10 pola $X$-ray (33 persen) dari 30 pola thresholding yang diujikan. Namun, apabila diamati lagi, kesalahan tersebut tidaklah terlalu besar jika dibandingkan keberhasilan yang didapat. Dan dari pengamatan kedua jenis citra (citra thresholding dan citra non-thresholding), dapat diambil kesimpulan bahwa penggunaan citra non-thresholding akan menghasilkan pengenalan lebih baik dari citra thresholding. Sehingga, pada saat mapping selanjutnya, citra-citra yang ingin diuji tidak perlu sebelumnya dilakukan proses thresholding. Pada Tabel 7 dapat dilihat perbedaan gambar X-ray Training dan NonTraining.

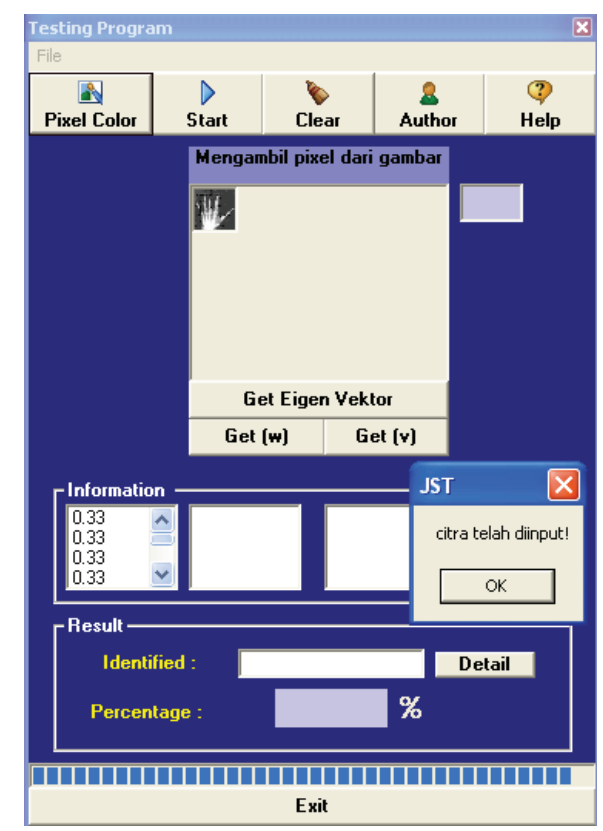

Gambar 15 Tampilan Form Testing JST Backpropagation 


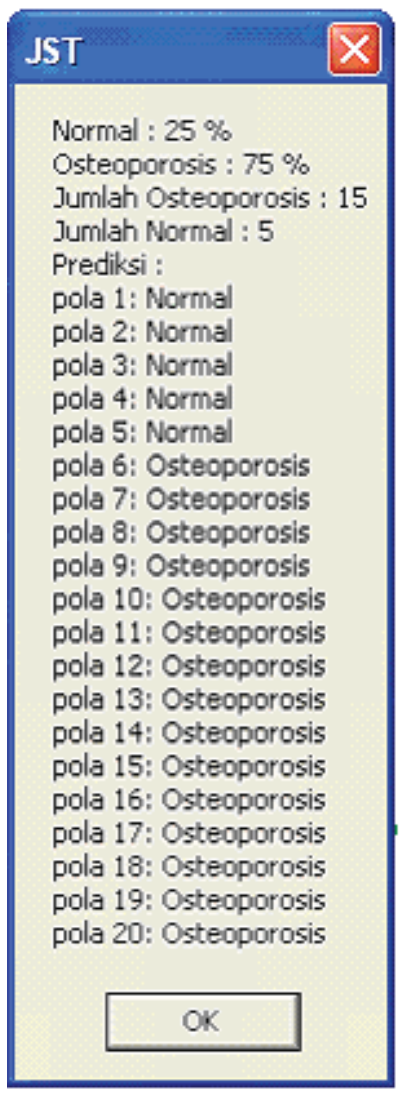

Gambar 16 Tampilan Detil Output Prediksi Penyakit

\section{PENUTUP}

Berdasarkan hasil-hasil yang telah dicapai selama perancangan, pembuatan, dan pengujian perangkat lunak tugas akhir ini, maka dapat disimpulkan bahwa: metode Backpropagation pada jaringan syaraf tiruan merupakan salah satu metode yang dapat digunakan untuk membuat aplikasi pengenalan atau pendeteksian dengan tingkat keberhasilan yang cukup baik, karena lebih dari 50 persen jumlah data citra yang di-input dan diuji dapat dikenali dengan benar; penggunaan nilai ambang thresholding sebesar 80, parameter learning rate sebesar 0.7, momentum sebesar 0.4, iterasi sebesar 100 epoch, unit-unit lapis tersembunyi sebanyak 10 buah, dan unit input sebanyak 600 unit menunjukkan sistem telah berhasil mengenali pola-pola X-ray learning dan kurang berhasil mengenali pola-pola X-ray non-learning; untuk mendapatkan bobot-bobot yang sesuai, diperlukan uji coba pelatihan yang berulang-ulang karena bobot-bobot yang dihasilkan dari pelatihan akan menentukan tingkat pengenalan pada proses mapping; serta pengujian dengan sejumlah 30 citra dari 10 citra yang dilatihkan dengan jumlah perbandingan uji masukan osteoporosis dan normal adalah 50:50 memiliki hasil persentase keberhasilan sebesar 73 persen dan kegagalan sebesar 27 persen.

\section{DAFTAR PUSTAKA}

Ahmad, U. (2005). Pengolahan Citra Digital dan Teknik Pemrogramannya. Yogyakarta: Graha Ilmu.

Anton, H. (1998). Aljabar Linier Elementer, Edisi kelima. Jakarta: Errlangga.

A Tutorial on Principal Component Analysis. (2002). http:// www.vision.auc.dk/sig/Teaching/Flerdim/Current/ hotteling/hotteling.htm, diakses Mei 2007.

Fowler, M. (2005). UML Distiled Panduan Singkat Tentang
Bahasa Pemodelan Objek Standar, Edisi ketiga. Yogyakarta: Andi.

Glosarium Data dan Informasi Kesehatan. (2005). http:// www.depkes.go.id, diakses Maret 2007.

Grant, J.V. Basmajian, dan Charles E. Slonecker. (1995). Metode Anatomi Berorientasi pada Klinik, Edisi kesebelas. Jakarta: Binarupa Aksara.

Hermawan, A. (2006). Jaringan Syaraf Tiruan Teori dan Aplikasi. Yogyakarta: Andi.

Jollife, I.T., (2002). Principal Component Analysis, $3^{\text {rd }}$ Edition. New York: Springer Verlag.

Manifestasi Klinis dan Penatalaksanaan Osteoporosis. (2004). http://www.dexa-medica.com/test/htdocs/ dexamedica/article_files/_osteoporosis.pdf, diakses Mei 2007.

Mardianto, I. (2007). Bahan Kuliah Sistem Jaringan Syaraf12 Principal Component Analysis. Jakarta: Jurusan FTIInformatika, Universitas Bina Nusantara.

Osteoporosis, Low Back Pain, and Other Bone Disorders. (2004).http://www.healthsquare.com/condition and treatment/condition_topic_index/osteoporosislowbackpain-otherbonedisorders.htm, diakses Juni 2007.

Perbandingan Morfometri Vertebrata Lumbal dengan Metacarpal Untuk Mendeteksi Dini Osteoporosis. (2007). http://med.unhas.ac.id/en/-Medical Faculty of Hasanuddin University, diakses Mei 2007.

Purnomo, H., Mauridhi, dan Agus K. (2006). Supervised Neural Network dan Aplikasinya. Yogyakarta: Graha Ilmu.

Putra, R. (2006). The Best Source Code Visual Basic. Jakarta: PT Gramedia.

Sadikin, R (2006). Bahan Kuliah Analisis Desain Sistem Pemodelan Use-case. Jurusan FTI-Informatika.

Siang, J.J. (2005). Jaringan Syaraf Tiruan dan Pemrogramannya Menggunakan Matlab. Yogyakarta: Andi.

Suplemen Kalsium Cegah Osteoporosis. (2007). http://www. MediaSehat.com, diakses Mei 2007.

------. Format File. http://slametriyanto.web.id/FormatFile. pdf, diakses Mei 2007.

------. Image. http://www.google.com.

------. Kelebihan PCX. http://tri1405.blogsome. com/2007/03/09/format-file-gambar-2-file-pcx, diakses Juli 2007.

------. Matrix. http://www.chemeng.ui.ac.id/s1/metnum/ matrix.htm, diakses Mei 2007.

-------. Matriks dan Komputasi. http://www.fisika.ui.ac.id/ matriks.htm, diakses Mei 2007.

------. Modul KLT. http://www.planetsourcecode.com, diakses Juni 2007.

------. Osteoporosis. http://www.mitrakeluarga.com/ informasi/osteoporosis.htm, diakses Mei 2007.

-------. Principle Component Analysis. http://dewey.petra. ac.id/spektra/module/catalog/docs/digital_thesis, diakses Mei 2007.

------. Rematologi. http://id.wikipedia.org/wiki/Rematologi, diakses Juni 2007.

------. Vektor dan Nilai Eigen. http://www.bluebit.gr/matrix/ eigenvalue-eigenvector.htm, diakses Juni 2007.

------.. http://www.cs.cmu.edu/ cil/v-images.html, diakses April 2007. 


\section{APPENDIX}

Tabel 2 Data Pengujian Berdasarkan Jumlah Unit Input Proses Training

\begin{tabular}{|c|c|c|c|c|c|}
\hline $\begin{array}{c}\text { Proses } \\
\text { Training }\end{array}$ & 1 & 2 & 3 & 4 & 5 \\
\hline Data Uji & 10 & 10 & 10 & 10 & 10 \\
\hline Unit Input & 400 & 500 & 600 & 700 & 800 \\
\hline Unit Hidden & 10 & 10 & 10 & 10 & 10 \\
\hline Unit Output & 1 & 1 & 1 & 1 & 1 \\
\hline Toleransi & 0,001 & 0,001 & 0,001 & 0,001 & 0,001 \\
\hline Learning Rate & 0,8 & 0,8 & 0,8 & 0,8 & 0,8 \\
\hline Momentum & 0,5 & 0,5 & 0,5 & 0,5 & 0,5 \\
\hline Epoch & 10000 & 10000 & 10000 & 10000 & 10000 \\
\hline $\begin{array}{l}\text { Treshold } \\
\text { Pengenalan Pola }\end{array}$ & $\begin{array}{c}0,55 \\
100 \% \\
\text { (epoch ke } 82 \text { ) }\end{array}$ & $\begin{array}{c}0,55 \\
100 \% \\
\text { (epoch ke 38) }\end{array}$ & $\begin{array}{c}0,55 \\
100 \% \\
\text { (epoch ke 35) }\end{array}$ & $\begin{array}{c}0,55 \\
100 \% \\
\text { (epoch ke 49) }\end{array}$ & $\begin{array}{c}0,55 \\
100 \% \\
\text { (epoch ke 52) }\end{array}$ \\
\hline Lama Training & $\begin{array}{l}174 \text { menit } \\
59 \text { detik }\end{array}$ & $\begin{array}{l}87 \text { menit } \\
13 \text { detik }\end{array}$ & $\begin{array}{l}70 \text { menit } 49 \\
\text { detik }\end{array}$ & $\begin{array}{l}102 \text { menit } \\
55 \text { detik }\end{array}$ & $\begin{array}{l}153 \text { menit } \\
30 \text { detik }\end{array}$ \\
\hline
\end{tabular}

Tabel 3 Data Pengujian Berdasarkan Jumlah Unit Hidden Proses Training

\begin{tabular}{|c|c|c|c|c|c|c|}
\hline $\begin{array}{l}\text { Proses } \\
\text { Training }\end{array}$ & 1 & 2 & 3 & 4 & 5 & 6 \\
\hline Data Uji & 10 & 10 & 10 & 10 & 10 & 10 \\
\hline Unit Input & 500 & 500 & 500 & 600 & 600 & 600 \\
\hline Unit Hidden & 5 & 15 & 20 & 5 & 15 & 20 \\
\hline Unit Output & 1 & 1 & 1 & 1 & 1 & 1 \\
\hline Toleransi & 0,001 & 0,001 & 0,001 & 0,001 & 0,001 & 0,001 \\
\hline Learning Rate & 0,8 & 0,8 & 0,8 & 0,8 & 0,8 & 0,8 \\
\hline Momentum & 0,5 & 0,5 & 0,5 & 0,5 & 0,5 & 0,5 \\
\hline Epoch & 10000 & 10000 & 10000 & 10000 & 10000 & 10000 \\
\hline Treshold & 0,55 & 0,55 & 0,55 & 0,55 & 0,55 & 0,55 \\
\hline $\begin{array}{l}\text { Pengenalan } \\
\text { Pola }\end{array}$ & $\begin{array}{c}100 \% \\
\text { (epoch ke 65) }\end{array}$ & $\begin{array}{c}100 \% \\
\text { (epoch ke 48) }\end{array}$ & $\begin{array}{c}100 \% \\
\text { (epoch ke 52) }\end{array}$ & $\begin{array}{c}100 \% \\
\text { (epoch ke 52) }\end{array}$ & $\begin{array}{c}100 \% \\
\text { (epoch ke 39) }\end{array}$ & $\begin{array}{c}100 \% \\
\text { (epoch ke 37) }\end{array}$ \\
\hline Lama raining & $\begin{array}{l}139 \text { menit } \\
40 \text { detik }\end{array}$ & $\begin{array}{l}120 \text { menit } \\
40 \text { detik }\end{array}$ & $\begin{array}{l}133 \text { menit } \\
34 \text { detik }\end{array}$ & $\begin{array}{l}104 \text { menit } \\
3 \text { detik }\end{array}$ & $\begin{array}{l}93 \text { menit } \\
19 \text { detik }\end{array}$ & $\begin{array}{l}98 \text { menit } \\
12 \text { detik }\end{array}$ \\
\hline
\end{tabular}

Tabel 4 Data Pengujian Berdasarkan Learning Rate Proses Training

\begin{tabular}{|c|c|c|c|c|c|c|}
\hline $\begin{array}{c}\text { Proses } \\
\text { Training }\end{array}$ & 1 & 2 & 3 & 4 & 5 & 6 \\
\hline Data Uji & 10 & 10 & 10 & 10 & 10 & 10 \\
\hline Unit Input & 500 & 500 & 500 & 600 & 600 & 600 \\
\hline Unit Hidden & 10 & 10 & 10 & 10 & 10 & 10 \\
\hline Unit Output & 1 & 1 & 1 & 1 & 1 & 1 \\
\hline Toleransi & 0,001 & 0,001 & 0,001 & 0,001 & 0,001 & 0,001 \\
\hline Learning Rate & 0,5 & 0,6 & 0,7 & 0,5 & 0,6 & 0,7 \\
\hline Momentum & 0,5 & 0,5 & 0,5 & 0,5 & 0,5 & 0,5 \\
\hline Epoch & 10000 & 10000 & 10000 & 10000 & 10000 & 10000 \\
\hline Treshold & 0,55 & 0,55 & 0,55 & 0,55 & 0,55 & 0,55 \\
\hline $\begin{array}{l}\text { Pengenalan } \\
\text { Pola }\end{array}$ & $\begin{array}{l}100 \% \\
\text { (epoch ke 49) }\end{array}$ & $\begin{array}{l}100 \% \\
\text { (epoch ke 13) }\end{array}$ & $\begin{array}{l}100 \% \\
\text { (epoch ke 17) }\end{array}$ & $\begin{array}{l}100 \% \\
\text { (epoch ke 103) }\end{array}$ & $\begin{array}{l}100 \% \\
\text { (epoch ke 26) }\end{array}$ & $\begin{array}{c}100 \% \\
\text { (epoch ke 5) }\end{array}$ \\
\hline $\begin{array}{l}\text { Lama } \\
\text { Training }\end{array}$ & $\begin{array}{l}102 \text { menit } \\
51 \text { detik }\end{array}$ & 25 menit 20 detik & $\begin{array}{l}33 \text { menit } \\
34 \text { detik }\end{array}$ & $\begin{array}{l}218 \text { menit } \\
22 \text { detik }\end{array}$ & $\begin{array}{l}55 \text { menit } \\
39 \text { detik }\end{array}$ & $\begin{array}{l}13 \text { menit } \\
13 \text { detik }\end{array}$ \\
\hline
\end{tabular}


Tabel 5 Data Pengujian Berdasarkan Momentum Proses Training

\begin{tabular}{|c|c|c|c|c|c|c|}
\hline $\begin{array}{c}\text { Proses } \\
\text { Training }\end{array}$ & 1 & 2 & 3 & 4 & 5 & 6 \\
\hline Data Uji & 10 & 10 & 10 & 10 & 10 & 10 \\
\hline Unit Input & 500 & 500 & 500 & 600 & 600 & 600 \\
\hline Unit Hidden & 10 & 10 & 10 & 10 & 10 & 10 \\
\hline Unit Output & 1 & 1 & 1 & 1 & 1 & 1 \\
\hline Toleransi & 0,001 & 0,001 & 0,001 & 0,001 & 0,001 & 0,001 \\
\hline Learning Rate & 0,7 & 0,7 & 0,7 & 0,7 & 0,7 & 0,7 \\
\hline Momentum & 0,4 & 0,7 & 0,8 & 0,4 & 0,7 & 0,8 \\
\hline Epoch & 10000 & 10000 & 10000 & 10000 & 10000 & 10000 \\
\hline Treshold & 0,55 & 0,55 & 0,55 & 0,55 & 0,55 & 0,55 \\
\hline $\begin{array}{l}\text { Pengenalan } \\
\text { Pola }\end{array}$ & $\begin{array}{c}100 \% \\
\text { (epoch ke 13) }\end{array}$ & $\begin{array}{c}100 \% \\
\text { (epoch ke 98) }\end{array}$ & $\begin{array}{c}100 \% \\
\text { (epoch ke 154) }\end{array}$ & $\begin{array}{c}100 \% \\
\text { (epoch ke 5) }\end{array}$ & $\begin{array}{c}100 \% \\
\text { (epoch ke 80) }\end{array}$ & $\begin{array}{c}100 \% \\
\text { (epoch ke 101) }\end{array}$ \\
\hline $\begin{array}{l}\text { Lama } \\
\text { Training }\end{array}$ & $\begin{array}{l}22 \text { menit } \\
11 \text { detik }\end{array}$ & $\begin{array}{l}168 \text { menit } \\
30 \text { detik }\end{array}$ & $\begin{array}{l}304 \text { menit } \\
1 \text { detik }\end{array}$ & $\begin{array}{l}11 \text { menit } \\
43 \text { detik }\end{array}$ & $\begin{array}{c}170 \text { menit } \\
3 \text { detik }\end{array}$ & $\begin{array}{l}207 \text { menit } \\
14 \text { detik }\end{array}$ \\
\hline
\end{tabular}

Tabel 6 Hasil Pengujian Mapping Pola X-ray Training

\begin{tabular}{ccc}
\hline X-Ray Tangan & Target & Output \\
\hline Citra 1 & 0 & 0 \\
Citra 2 & 0 & 0 \\
Citra 3 & 0 & 0 \\
Citra 4 & 0 & 0 \\
Citra 5 & 0 & 0 \\
Citra 6 & 1 & 1 \\
Citra 7 & 1 & 1 \\
Citra 8 & 1 & 1 \\
Citra 9 & 1 & 1 \\
Citra 10 & 1 & 1 \\
\hline
\end{tabular}

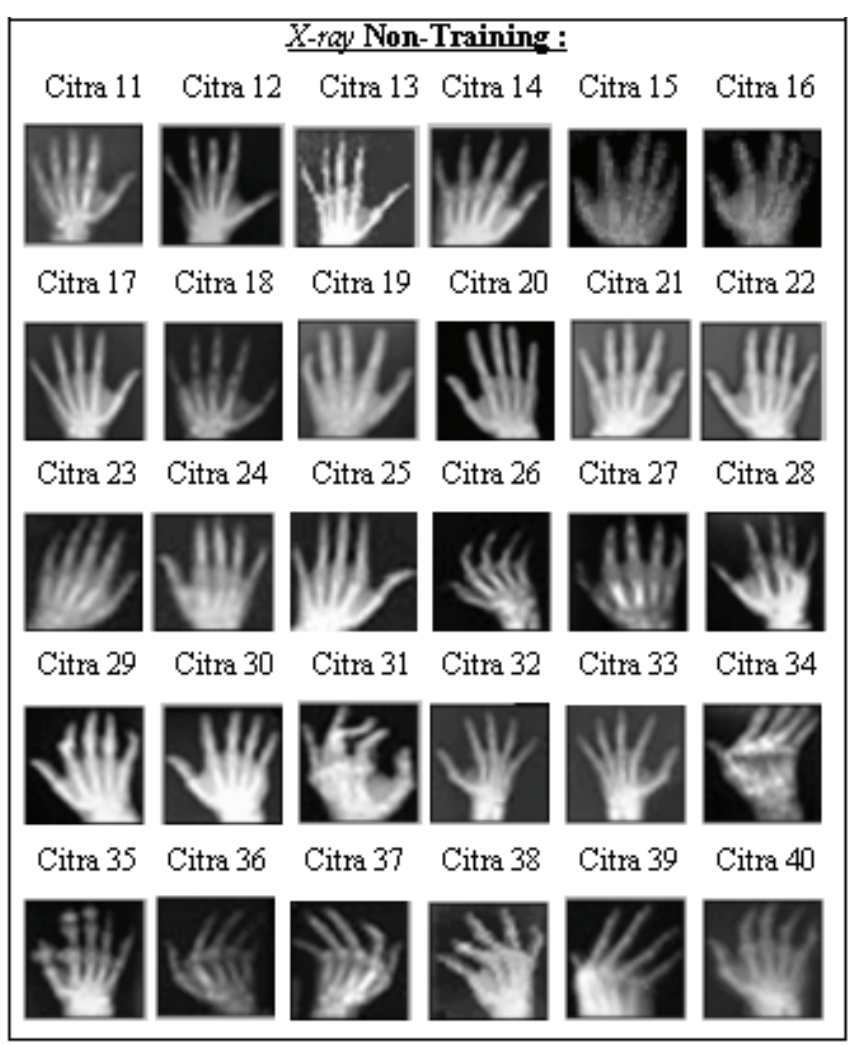

Tabel 7 X-ray Training dan Non-Training

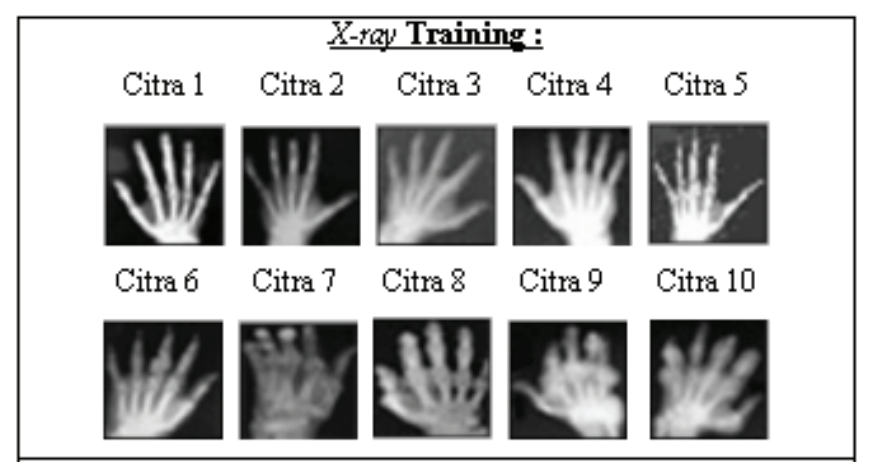




\begin{tabular}{ccccc}
\hline $\begin{array}{c}\text { X-Ray } \\
\text { (Non-Thresholding) }\end{array}$ & $\begin{array}{c}\text { X-Ray } \\
\text { (Thresholding) }\end{array}$ & Target & $\begin{array}{c}\text { Output } \\
\text { (Non-Thresholding) }\end{array}$ & $\begin{array}{c}\text { Output } \\
\text { (Thresholding) }\end{array}$ \\
\hline Citra 11 & Citra 11 & 0 & 0 & 0 \\
Citra 12 & Citra 12 & 0 & 0 & 0 \\
Citra 13 & Citra 13 & 0 & 0 & 0 \\
Citra 14 & Citra 14 & 0 & 0 & 0 \\
Citra 15 & Citra 15 & 0 & 0 & 0 \\
Citra 16 & Citra 16 & 0 & 0 & 1 \\
Citra 17 & Citra 17 & 0 & 0 & 1 \\
Citra 18 & Citra 18 & 0 & 1 & 1 \\
Citra 19 & Citra 19 & 0 & 1 & 1 \\
Citra 20 & Citra 20 & 0 & 1 & 1 \\
Citra 21 & Citra 21 & 0 & 1 & 1 \\
Citra 22 & Citra 22 & 0 & 1 & 1 \\
Citra 23 & Citra 23 & 0 & 1 & 1 \\
Citra 24 & Citra 24 & 0 & 1 & 1 \\
Citra 25 & Citra 25 & 0 & 1 & 1 \\
Citra 26 & Citra 26 & 1 & 1 & 1 \\
Citra 27 & Citra 27 & 1 & 1 & 1 \\
Citra 28 & Citra 28 & 1 & 1 & 1 \\
Citra 29 & Citra 29 & 1 & 1 & 1 \\
Citra 30 & Citra 30 & 1 & 1 & 1 \\
Citra 31 & Citra 31 & 1 & 1 & 1 \\
Citra 32 & Citra 32 & 1 & 1 & 1 \\
Citra 33 & Citra 33 & 1 & 1 & 1 \\
Citra 34 & Citra 34 & 1 & 1 & 1 \\
Citra 35 & Citra 35 & 1 & 1 & 1 \\
Citra 36 & Citra 36 & 1 & 1 & 1 \\
Citra 37 & Citra 37 & 1 & 1 & 1 \\
Citra 38 & Citra 38 & 1 & 1 & 1 \\
Citra 39 & Citra 39 & 1 & 1 & 1 \\
Citra 40 & Citra 40 & 1 & 1 & 1 \\
& & 1 & 1 \\
\hline & & 1 & 1 \\
\hline
\end{tabular}

